\title{
The Process of Xylanase Production from Bacillus pumilus RXAIII-5
}

\author{
NUR RICHANA ${ }^{1 \ddagger \star}$, TUN TEDJA IRAWADI ${ }^{1}$, M. ANWAR NUR ${ }^{1}$, \\ ILLAH SAILAH ${ }^{2}$, AND KHASWAR SYAMSU² \\ ${ }^{1}$ Department of Chemistry, Faculty of Mathematics and Natural Sciences \\ ${ }^{2}$ Department of Agroindustrial Technology, Faculty of Agroindustrial Technology \\ Institut Pertanian Bogor, Darmaga Campus, Bogor 16680, Indonesia
}

\begin{abstract}
The optimum conditions for the growth of Bacillus pumilus RXAIII-5 (a potential xylanase producer) were sought, these included temperature, $\mathrm{pH}$, aeration, and agitation of the culture batch. Afterwards a mathematical model based on the parameter of cultivation kinetics was formulated. At the same time, the rheology of the fluid used for bacterial cultivation in a bioreactor was studied. The data obtained was used for estimating the 'scaling up' of enzyme production. The results of the study indicate that the optimum condition for processing in $50 \mathrm{ml}$ Erlenmeyer flask are used temperature of $35^{\circ} \mathrm{C}\left(308^{\circ} \mathrm{K}\right), \mathrm{pH} 7$, and an agitation rate of $140 \mathrm{rpm}$. The highest xylanase activity and its specific activity are $297.132 \mathrm{U} \cdot \mathrm{ml}^{-1}$ and $655.32 \mathrm{U}^{-1}{ }^{-1}$ protein, respectively. Subsequent experiments in a bioreactor using all of the experiment parameters mentioned above, except for the agitation rate, shows that the results are as follows. The highest specific growth was at 0.082 hour $^{-1}$ at an aeration and agitation rate of $0.5 \mathrm{vvm}$ and $150 \mathrm{rpm}$, respectively. Based on the data of the cultivation kinetics, the optimum conditions for the fermentation in Biostat $2 \mathrm{~L}$-bioreactor is $1 \mathrm{vvm}$ and $200 \mathrm{rpm}$ of aeration and agitation, respectively.

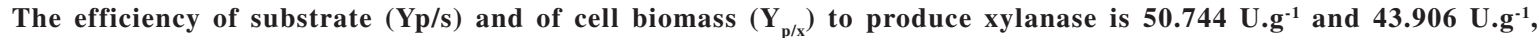
respectively. The efficiency of substrate to cell production $\left(\mathrm{Y}_{\mathrm{x} / \mathrm{s}}\right)$ is $1.178 \mathrm{~g} . \mathrm{g}^{-1}$. The liquid cultivation-medium has non-Newtonian properties. Based on a mathematical model it is found that the consistency index (k constant) and index of liquid behavior ( $\mathrm{n}$ value) are $0.179 \mathrm{~g} . \mathrm{cm}^{-1}$.second ${ }^{-1}$ and 0.3212 , respectively. Becouse the value of $0<n<1$ and the constant $k>0$, the culture liquid is categorized as pseudo plastic one. The Rheynold number (NRe) is $6.9 \times 10^{3}$ which indicates it has turbulent characteristics. From a calculation it is found that the power required to run a suitably sized impeller is 0.228 HP (Horse Power) and the power consumption per unit volume is $0.2265 \mathrm{HP}^{-3} \mathrm{~m}^{-3}$. All these values were used for scaling up xylanase production in the bioreactor.
\end{abstract}

Key words: Bacillus pumilus, xylanase, production

Xylanase is a group of extracellular enzymes which are able to hydrolyze hemicelullosic materials into xylose and xylo-oligosaccharides. Xylanases show great potential for industrial applications mainly for the bioconversion of lignocelluloses to sugar, ethanol, and other useful substances, clarification of juices and wines, improving the nutritional quality of silage and green feed and the de-inking processes of waste papers (Viikari et al. 2001). The enzymes have been grouped based on the type of substrate hydrolized. Xylanases are categorized into three groups: $\beta$-xylosidase, exoxylanase and endoxylanase. Endoxylanase is the main enzyme responsible for the cleavage of the linkages within the xylan backbone (Belfaquih et al. 2002). Only a few microorganisms are capable of producing xylanase extracelullarly. Some findings indicated that bacteria (Gilbert and Hazlewood 1993; Sunna and Antranikian 1997), fungi (Tonukari et al. 2002; Kheng and Omar 2005), actinomycetes (Ball and McCarthy 1989; Begg et al. 2001), and yeast (Hrmova et al. 1984; Liu et al. 1999) were capable of producing xylanase. Xylanase-producing alkaliphillic bacteria can be used as bleaching agent for paper processing (Ruiz-Arribas et al. 1995).

₹Present address and *Corresponding author, Indonesian Center for Agricultural Postharvest Research and Development, Pusat Penelitian dan Pengembangan Pertanian, Jalan Tentara Pelajar No 12, Bogor 16114, Indonesia; Phone: +62-251-7177064, Fax: +62-251-321762, E-mail: r1ch4n4@yahoo.co.id
Cultivation of xylanase-producing microorganisms in a liquid medium has been applied widely in producing the enzyme. There are many advantages in using a liquid medium, i.e. the type of component and composition of the medium are easy to adjust to obtain the optimum conditions for microbial growth; more efficient consumption of substrate easier in adjusting the microorganism growth rate; and the risk of contamination is less compared to using a solid medium. However, the cultivation in liquid medium required skills and expertise in operating a bioreactor for obtaining a high level of enzyme production. By shaking the liquid medium, it is expected that temperature, $\mathrm{pH}$, oxygen, nutrient supply as well as other environmental factors are homogenous throughout the medium in the bioreactor.

The engineering on the processing of xylanase production is based on the information obtained through studying on the optimization process, the strategy on the studying optimum level of substrate, and then the modeling competency of the fermentation industry. All these cover the studies on the cultivation kinetics based on three rates i.e. the rates of biomass production, of substrate consumption and of enzyme production.

Production of xylanase from isolate bacteria capable of utilizing xylan for growth substrate as carbon source. In general, the agro-residues such as wheat bran, sugar cane bagasse, corn cob, paddy straw, rice husks, and cassava wastes were found to be more suitable like xylan (Saurabh $e t$ al. 2001; Richana et al. 2004). Saha (2002) reported structure 
of xylan in corb fiber is commercially available enzyme preparation.

This work was conducted to study the ability of Bacillus pumilus RXAIII-5 in producing xylanase using corn cobs as a substrate. Optimum conditions such as agitation, aeration, and the time course for bacterial cultivation are designed to favor bacterial growth. From the study it is expected that the parameters of cultivation kinetics will be obtained. There can be used as a basic strategy to optimize the amounts of substrate added. The study of rheology of the liquid medium in cultivation is also conducted for the purposes of scaling up of a bioreactor system.

\section{MATERIALS AND METHODS}

The experiment was carried out over the period December 2002 to September 2003. To determine the effect of $\mathrm{pH}$ and temperature on the growth of $B$. pumilus RXAIII-5, the temperature used were $25-50{ }^{\circ} \mathrm{C}\left(298-323^{\circ} \mathrm{K}\right), \mathrm{pH}$ 7-11 and agitation 100-160 rpm. Ten percent of inoculants were placed in $100 \mathrm{ml}$ Erlenmeyer flask. Composition of growth medium was $0.125 \%(\mathrm{wt} / \mathrm{vol})$ bactopeptone, $0.05 \%$ (wt/vol) yeast extract, 3.04\% (wt/vol) corn cob xylan, $0.08 \%$ (wt/vol) $\mathrm{KH}_{2} \mathrm{PO}_{4}$, and $0.02 \%(\mathrm{wt} / \mathrm{vol}) \mathrm{MgSO}_{4} \cdot 7 \mathrm{H}_{2} \mathrm{O}$ (Richana et al. 2004).

Surface Response Method Box-Behnker experimental design using 3 variables was used for finding the optimum conditions for cultivation. Observations were carried out on the biomass production, xylanase activity, soluble protein content and substrate residue.

Cultivation Kinetics in Biostat B-21 Bioreactor. Xylanase production using 1 liter of medium in a bioreactor was conducted at the optimum condition $\left(\mathrm{T}=35^{\circ} \mathrm{C} / 308^{\circ} \mathrm{K}\right.$, $\mathrm{pH}$ 7) obtained from the previous experiments. In this experiment the agitation rate was varied between 150, 200, and $250 \mathrm{rpm}$ and the aeration was adjusted between 0.5 and $1.0 \mathrm{vvm}$ (air volume per medium volume per minute). The $\mathrm{pH}$ of the medium was controlled by automatic addition of $\mathrm{NaOH}$ and $\mathrm{HCl}$. Silicone was also added as an antifoaming agent. Sample of the culture were withdrawn at $0,2,4,6,8,12,16$, $20,24,32,36,40,44$, and $48 \mathrm{~h}$ after the inoculation.

Observations were conducted on the cell biomass, enzyme activity and the soluble protein content. Cell biomass was separated by pelleting using centrifugation at 10,000 $\mathrm{xg}$ (centrifugal force). Soluble protein was determined by the method of Bradford (1976) using 100-800 ppm Bovine Serum Albumin (BSA) is standard. Absorbance of the reaction mixture was determined by spectrophotometrically at $\lambda=600 \mathrm{~nm}$. Xylanase activity was determined by the ability of enzyme to hydrolyze xylan into invert sugar according to the method of Winterhalter and Liebl (1995). Analyses of invert sugar used the DNS (3,5-dinitro salysilic acid) method and spectrophotometry at $\ddot{e}=550 \mathrm{~nm}$. One unit of xylanase activity is the amount of enzyme which is able to convert xylan to produce 1 ìmol invert sugar (or xylose) per min. (Kubata $e t$ al. 1992). A series of xylose standards was used.

Combination of agitation and aeration rates was used to calculate the parameter kinetics, in which a mathematical model was developed to explain the system dynamics on the transformation of cell, substrate, and products during cultivation. In this experiment the Monod (1949) mathematical equation was used as follow:

$$
\begin{aligned}
& \mathrm{dX} / \mathrm{dt}=\mathrm{ì} \mathrm{X} \text { (cell biomass) } \\
& \grave{i}=\grave{i}_{\max } \cdot S /\left(\mathrm{K}_{\mathrm{s}}+\mathrm{S}\right) \text { or } 1 / \hat{\imath}=\left(\mathrm{K}_{\mathrm{s}} \hat{\mathrm{i}}_{\text {max }}\right)(1 / \mathrm{S})+1 / \mathrm{i}_{\text {max }} \\
& \mathrm{dS} / \mathrm{dt}=\mathrm{Y}_{\mathrm{p} / \mathrm{s}} \mathrm{dS} / \mathrm{dt} \text { (substrate) } \\
& \mathrm{dP} / \mathrm{dt}=\mathrm{Y}_{\mathrm{p} / \mathrm{x}} \mathrm{dX} / \mathrm{dt} \text { (xylanase activity) } \\
& \mathrm{Y}_{\mathrm{p} / \mathrm{s}}=-\mathrm{dP} / \mathrm{dS}=\text { the efficiency of substrate consumption to } \\
& \text { produce enzyme } \\
& \mathrm{Y}_{\mathrm{x} / \mathrm{s}}=-\mathrm{dX} / \mathrm{dS}=\text { the efficiency of substrate consumption to } \\
& \text { biomass } \\
& \mathrm{Y}_{\mathrm{p} / \mathrm{x}}=\mathrm{dP} / \mathrm{dX}=\text { the efficiency of biomass to produce } \\
& \text { enzyme, where }
\end{aligned}
$$

X: cell concentration (g. $1^{-1}$ ), S: substrate concentration $\left(\mathrm{g} . \mathrm{l}^{-1}\right)$, $\mathrm{P}$ : product concentration, $\mathrm{t}$ : fermentation time (hour), $\mathrm{U}$ : specific growth rate $\left(1\right.$.hour $\left.{ }^{-1}\right), \mathrm{k}_{\mathrm{s}}$ : constant $\left(\mathrm{g} \cdot \mathrm{l}^{-1}\right), \mathrm{ì}_{\max }$ : specific maximum of growth rate $\left(1 . \mathrm{jam}^{-1}\right)$. Parameter kinetics consisting of $\grave{i}_{\max }, Y_{p / s}, Y_{x / s}, Y_{p / x}$ were determined based on experimental data using a nonlinear regression technique (Scragg 1991).

The Rheology of the Liquid Culture. The density of the liquid culture was determined using picnometer (weight per volume), and its viscosity using aBrookfield Viscometer at 6 , $12,30,60 \mathrm{rpm}$ having a spindle number of 2 . Data of viscosity, shear rate and shear strength were recorded. From these, the consistency index (k) and liquid index (n) was calculated. The Rheynolds number (NRe) was determined as follows:

$$
\mathrm{NRe}=\left(\mathrm{N}_{1} \mathrm{D}_{1}^{2} \tilde{\mathrm{n}}\right) / \grave{\mathrm{i}}_{\mathrm{a}}
$$

$\mathrm{N}=$ shaking speed, $\mathrm{D}=$ diameter of impeller, $\rho=$ density, ì a= viscosity, $\mathrm{n}$ liquid index.

These data, combined with the data obtained from the run of Biostat-21 bioreactor, enabled the power needed to run the impeller to be calculated. Power consumption for the impeller was then calculated using the equation presented as follows:

$$
\mathrm{P}=\left(\tilde{\mathrm{n}} \mathrm{N}^{3} \mathrm{D}_{1}^{5} \mathrm{~Np}\right) / \mathrm{g}_{\mathrm{c}}
$$

$\mathrm{P}=$ power consumption, $\mathrm{Np}=$ power number, $\mathrm{g}_{\mathrm{c}}=$ gravitation $=9.81 \mathrm{~g} \mathrm{~cm} / \mathrm{g} \mathrm{sec}^{2}$.

Bioreactor scaling up was calculated based on the power consumption per unit of volume.

\section{RESULT}

Optimum Conditions for the Growth of Bacillus pumilus RXAIII-5. This work was designed to study the effect of temperature, $\mathrm{pH}$ and the rate of agitation in an effort to obtain optimum conditions for the growth of the bacterium. The quadratic-response-curve model was used in the analyses of variance (Table 1). It was found that there was no significant effect of temperature, $\mathrm{pH}$ and the rate of agitation on soluble protein content.

Analyses of variance of xylanase activity indicates that the mathematical model used fits very significantly. The coefficient of determination (R2) is 0.962 which means there is less than $4 \%$ of variance which does not fit the model. 
Table1 Analysis of variance for soluble protein, xylanase activity and specific activity of liquid culture of B. pumilus RXAIII-5

\begin{tabular}{lccc}
\hline Source of variance & Protein xylanase & Activity $^{\mathrm{a}}$ & ${\text { Specific } \text { activity }^{\mathrm{b}}}^{\text {Regression Model }}$ \\
\hline Linear & $\mathrm{ns}$ & $* *$ & $* *$ \\
Quadratic & $\mathrm{ns}$ & $* *$ & $* *$ \\
$\mathrm{R}^{2}$ & $\mathrm{~ns}$ & $* *$ & $* *$ \\
Mean & 0.778 & 0.96 & 0.97 \\
$\mathrm{X} 1=$ Temperature & 0.433 & 105.92 & 245.90 \\
$\mathrm{X} 2=\mathrm{pH}$ & $\mathrm{ns}$ & $\mathrm{ns}$ & $\mathrm{ns}$ \\
$\mathrm{X} 3=\mathrm{rpm}$ & $\mathrm{ns}$ & $* *$ & $* *$ \\
$(\mathrm{X} 1)(\mathrm{X} 2)$ & $\mathrm{ns}$ & $\mathrm{ns}$ & $*$ \\
$(\mathrm{X} 1)(\mathrm{X} 3)$ & $\mathrm{ns}$ & $\mathrm{ns}$ & $\mathrm{ns}$ \\
$(\mathrm{X} 2)(\mathrm{X} 3)$ & $\mathrm{ns}$ & $\mathrm{ns}$ & $\mathrm{ns}$ \\
$(\mathrm{X} 1)(\mathrm{X} 2)(\mathrm{X} 3)$ & $\mathrm{ns}$ & $*$ & $*$ \\
\hline
\end{tabular}

*Significantly different, $* *$ Very significantly different, $\mathrm{ns}=$ not sig-

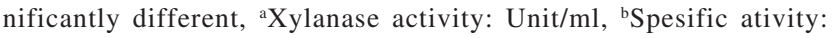
Unit xilanase/mg protein.

Variation of temperature, $\mathrm{pH}$ and shaking speed is greatly affected xylanase activity. Interaction effects upon xylanase activity is shown only by the two parameter of $\mathrm{pH}$ and shaking speed. Application of the quadratic response model shows an empirical relationship between xylanase activity and the test variable and unit code with a regression equation as follows:

$$
\begin{gathered}
\mathrm{Y}=1010.958-22.639 \mathrm{X} 1-365.38 \mathrm{X} 2+22.128 \mathrm{X} 3+ \\
0.178 \mathrm{X} 1 * \mathrm{X} 1+0.872 \mathrm{X} 2 * \mathrm{X} 1+21.735 \mathrm{X} 2 * \mathrm{X} 2- \\
0.0108 \mathrm{X} 3 * \mathrm{X} 1-0.872 \mathrm{X} 3 * \mathrm{X} 2-0.0536 \mathrm{X} 3 * \mathrm{X} 3 \\
\text { where } \mathrm{X} 1 \text { : temperature, } \mathrm{X} 2: \mathrm{pH}, \text { and } \mathrm{X} 3: \mathrm{rpm} .
\end{gathered}
$$

Maximum xylanase activity is $297.13 \mathrm{U}_{\mathrm{ml}}^{-1}$ at $\mathrm{pH}$ 7, temperature $35^{\circ} \mathrm{C}$, and an agitation rate of $140 \mathrm{rpm}$ (Fig 1). Minimum xylanase activity is $42.71 \mathrm{U}^{-\mathrm{ml}^{-1}}$ at $\mathrm{pH} 9.9,42{ }^{\circ} \mathrm{C}$, and $120.89 \mathrm{rpm}$ for $\mathrm{pH}$, temperature and agitation, respectively. These data indicate the minimum conditions in which $B$. pumilus RXAIII-5 can survive and produce xylanase.

The results of the analyses of variance on specific activity are similar to those of xylanase activity, i.e. the presumed model fits very well. There is a highly significantly effect of $\mathrm{pH}$ on xylanase activity and specific activity for both the linear as well as the quadratic models. However, the effect of the interaction between $\mathrm{pH}$ and agitation rate on both xylanase activity and specific activity is small. Application of quadratic response model shows an empirical relationship between xylanase activity and test variable and unit code with its regression equation as follows:

$$
\begin{gathered}
\mathrm{Y}=2217.857-37.77 \mathrm{X} 1-846.99 \mathrm{X} 2+48.03 \mathrm{X} 3+ \\
0.399 \mathrm{X} 1 * \mathrm{X} 1+0.74 \mathrm{X} 2 * \mathrm{X} 1+52.61 \mathrm{X} 2 * \mathrm{X} 2-0.05 \mathrm{X} 3 * \mathrm{X} 1- \\
1.84 \mathrm{X} 3 * \mathrm{X} 2-0.12 \mathrm{X} 3 * \mathrm{X} 3 \\
\text { where X1: temperature, } \mathrm{X} 2: \mathrm{pH}, \mathrm{X} 3: \mathrm{rpm} .
\end{gathered}
$$

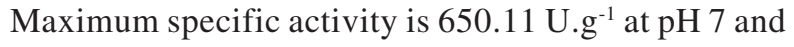
$35.2{ }^{\circ} \mathrm{C}$ calculated from the quadratic mathematical model (Fig 1).

The Optimization of Agitation and Aeration in a 2 l Bioreactor. The work on the optimization of agitation and aeration of the liquid medium was conducted in a 21 bioreactor. The aeration rates were 0.5 and $1.0 \mathrm{vvm}$ and the agitation rates were 200,150 , and $100 \mathrm{rpm}$. Sample were taken to estimate on the dry weight of the cell mass, protein content and xylanase activity.

Dry Weight of Cell. Fig 2. indicates that the adaptation phase for the bacterial growth lasted for $6 \mathrm{~h}$ for the culture in all treatments. The same goes for the exponential phase, the phase of the culture of all treatments lasted for $30 \mathrm{~min}$. The highest bacterial growth $\left(2.802 \mathrm{~g} \mathrm{l}^{-1}\right)$ of liquid culture was obtained at $200 \mathrm{rpm}$ and $1 \mathrm{vvm}$ of agitation and aeration rates, respectively. This was followed $\left(2.523 \mathrm{~g} \mathrm{l}^{-1}\right)$ by $150 \mathrm{rpm}$ and $0.5 \mathrm{vvm}$ of agitation and aeration rates respectively. Results mentioned above fit the theory that the oxygen consumption rate by aerobic microorganisms is high enough, but insufficient oxygen supply will decrease yield.

Soluble Protein. Total soluble protein content is used as one of the parameters to measure enzyme production. The
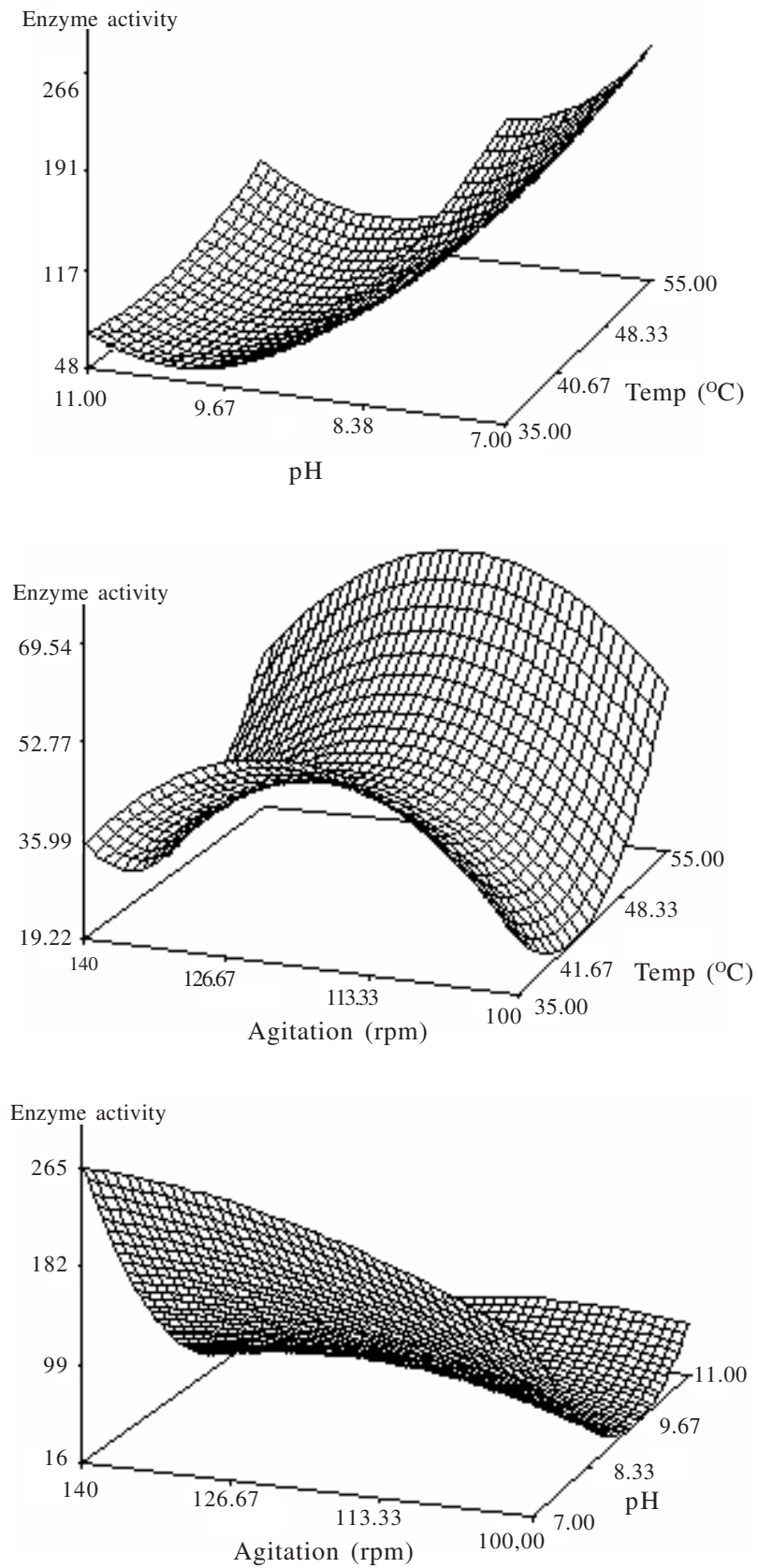

Fig 1 Interaction effect among treatments (temperature, $\mathrm{pH}$, agitation) on the xylanase activity of $B$. pumilus RXAIII-5. 
a

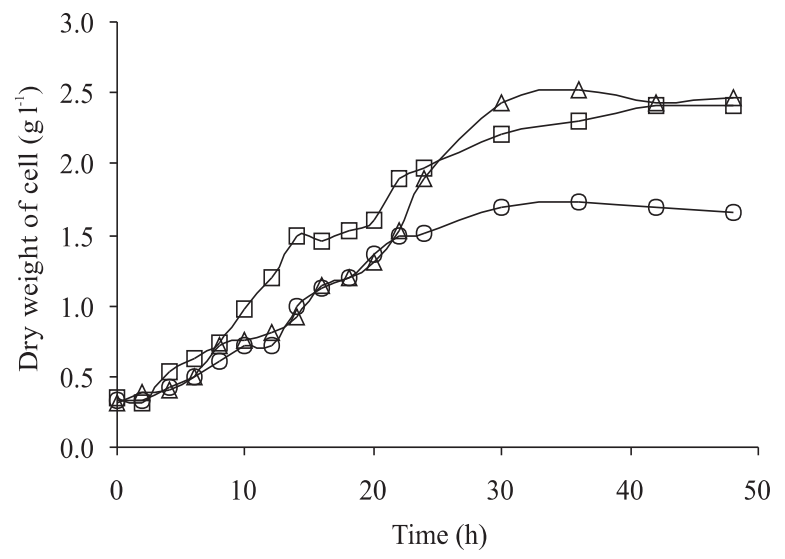

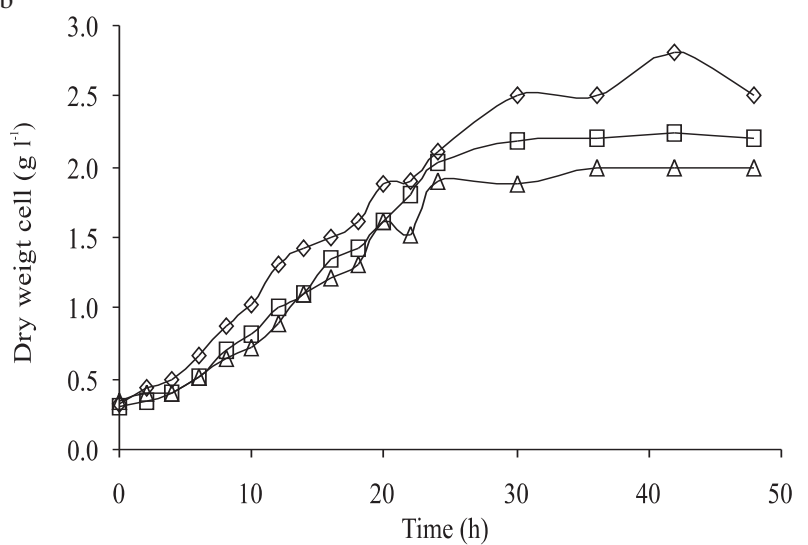

Fig 2 Several growth curves of B. pumilus RXAIII-5 with various agitation rates and two aeration rates (a: 0.5 vvm and b: 1 vvm). Cell dry weight is plotted against time. ( $\square-) 200 \mathrm{rpm},(-\triangle) 150 \mathrm{rpm},(-\mathrm{O}-) 100 \mathrm{rpm}$.
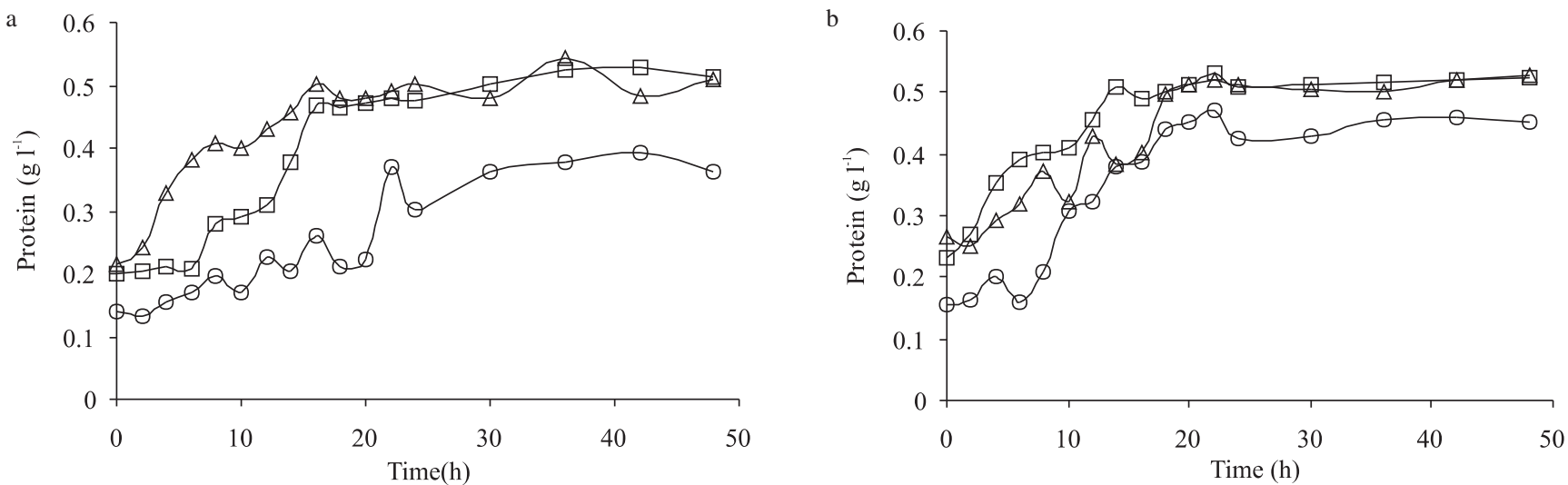

Fig 3 Curves of total soluble protein at aeration rates of a: $1.0 \mathrm{vvm}$ and b: $0.5 \mathrm{vvm}$ using three agitation rates. ( $\square-)$ ) $200 \mathrm{rpm},(-\triangle-) 150 \mathrm{rpm}$, (-O- ) $100 \mathrm{rpm}$.
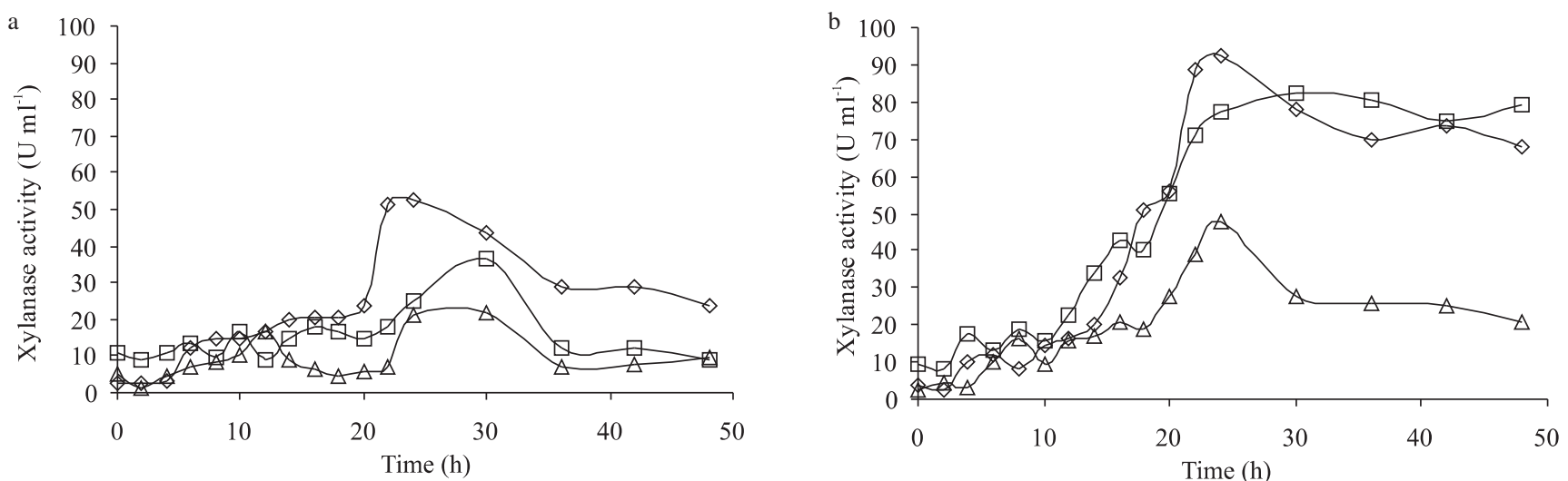

Fig 4 Curves of xylanase activity at aeration rates of a: $1.0 \mathrm{vvm}$ and b: $0.5 \mathrm{vvm}$ using three agitation rates. ( $\frown-)$ Akt (200 rpm), ( $\square-)$ Akt $(150 \mathrm{rpm}),(-\neg)$ Akt (100 rpm).

data obtained showed a similar increased pattern of total soluble protein content, cell dry weight and xylanase activity. The highest total soluble protein content was recorded using agitation rate of 150 and aeration rates at 0.5 and $1.0 \mathrm{vvm}$ (Fig 3).

Xylanase Activity. Xylanase activity of B. pumilus RXAIII5 in the liquid culture was not detectable before $10 \mathrm{~h}$ after inoculation. In almost all treatments, the optimum xylanase activity was at 24 to $30 \mathrm{~h}$ after inoculation, and from then on the xylanase activity decreased. The highest xylanase activity was produced at an aeration rate of 0.5 and $1.0 \mathrm{vvm}$ and at agitation rate of $200 \mathrm{rpm}$ compared to those of the other combinations treatments (Fig 4). The highest xylanase activity, $92.52 \mathrm{U} \mathrm{ml}^{-1}$, was detected at $24 \mathrm{~h}$ after inoculation with an agitation rate of $200 \mathrm{rpm}$ and an aeration rate of 1 vvm. The smallest xylanase activity was recorded at $100 \mathrm{rpm}$ and $0.5 \mathrm{vvm}$ of agitation and aeration rates, respectively. This was due to the lower aeration rate resulting in a lower oxygen supply which slowed metabolism there by producing less enzymes, including xylanase.

Cultivation Kinetics of $B$. pumilus RXAIII-5. The data on the effect of aeration and agitation was processed similarly to the above using the Monod equation (Monod 
Table 2 Value for $\mathrm{Yp} / \mathrm{s}, \mathrm{Yp} / \mathrm{x}$, and $\mathrm{Yx} / \mathrm{s}$ of liquid culture of $B$. pumilus RXAIII-5 at various aeration and agitation rates

\begin{tabular}{ccccrr}
\hline Aeration $(\mathrm{vvm})$ & Agitation $(\mathrm{rpm})$ & Specific growth $\left(\mathrm{i} \mathrm{h}^{-1}\right)$ & $\mathrm{Yx} /{\mathrm{s}\left(\mathrm{g} \mathrm{g}^{-1} \text { substrate }\right)}$ & $\mathrm{Yp} /{\mathrm{s}\left(\mathrm{U} \mathrm{g} \mathrm{g}^{-1} \text { substrate }\right)}^{\text {Yp/x }\left(\mathrm{U} \mathrm{g}{ }^{-1} \text { biomass }\right)}$ \\
\hline 0.5 & 200 & $0.078 \pm 0.003$ & $1.057 \pm 0.123$ & $26.295 \pm 2.643$ & $25.272 \pm 2.370$ \\
0.5 & 150 & $0.082 \pm 0.013$ & $0.757 \pm 0.055$ & $12.535 \pm 2.473$ & $9.176 \pm 1.812$ \\
0.5 & 100 & $0.067 \pm 0.012$ & $0.757 \pm 0.082$ & $9.665 \pm 1.186$ & $11.755 \pm 1.771$ \\
1 & 200 & $0.081 \pm 0.002$ & $1.178 \pm 0.132$ & $50.744 \pm 7.706$ & $43.906 \pm 7.127$ \\
1 & 150 & $0.081 \pm 0.001$ & $0.956 \pm 0.096$ & $39.124 \pm 6.799$ & $42.075 \pm 7.490$ \\
1 & 100 & $0.072 \pm 0.007$ & $0.962 \pm 0.093$ & $22.090 \pm 3.674$ & $20.088 \pm 3.307$ \\
\hline
\end{tabular}

$\pm:$ standard deviasi, Yx/s: The efficiency of substrate consumption for the cell biomass production, Yp/s: The efficiency of substrate consumption for the enzyme production, $\mathrm{Yp} / \mathrm{x}$ : The efficiency of the enzyme production by cell biomass.
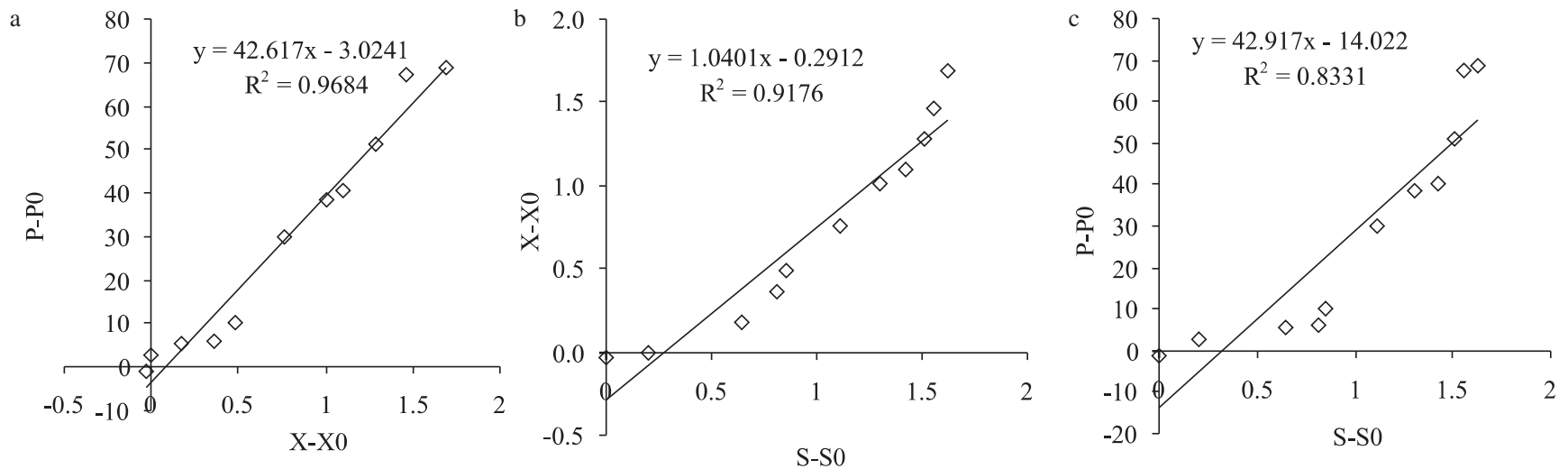

Fig 5 Linear regression of $\mathrm{Y}_{\mathrm{p} / \mathrm{s}}$ (a), $\mathrm{Y}_{\mathrm{x} / \mathrm{s}}$ (b), and $\mathrm{Y}_{\mathrm{p} / \mathrm{x}}$ (c) for liquid culture of B. pumilus RXAIII-5.

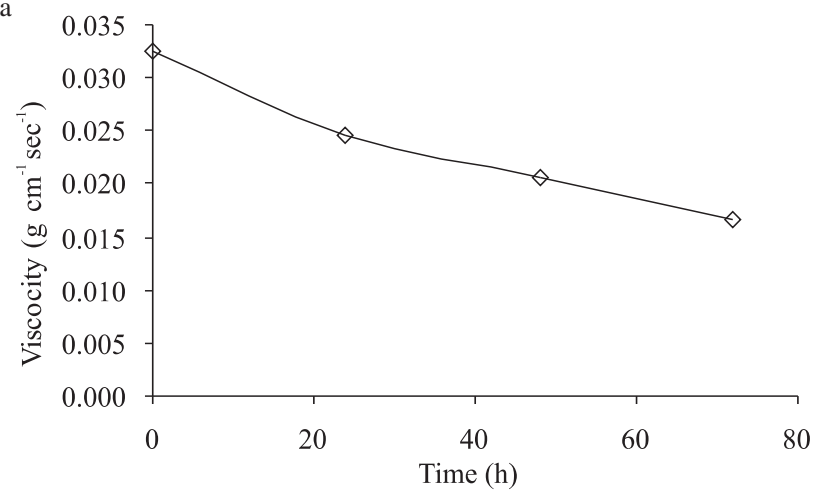

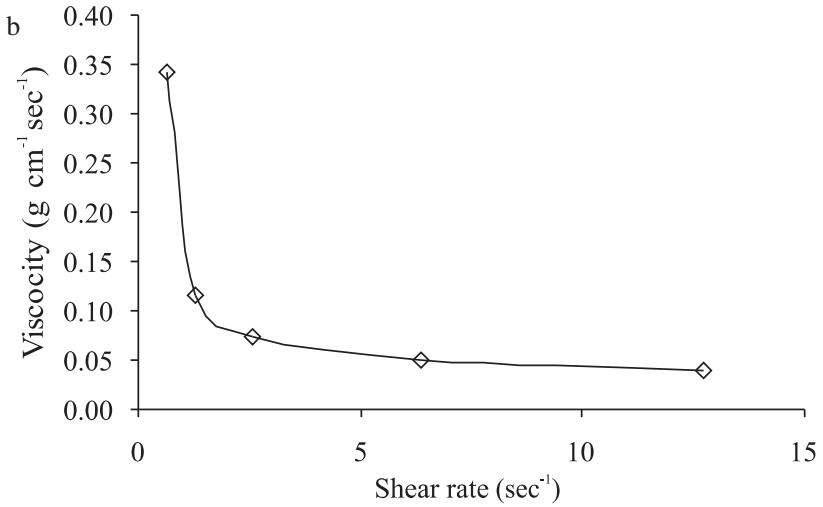

Fig 6 Rheology of liquid culture of B. pumilus RXAIII-5 (A: relationship of viscosity and time of fermentation, B: relationship of viscosity and shear rate).

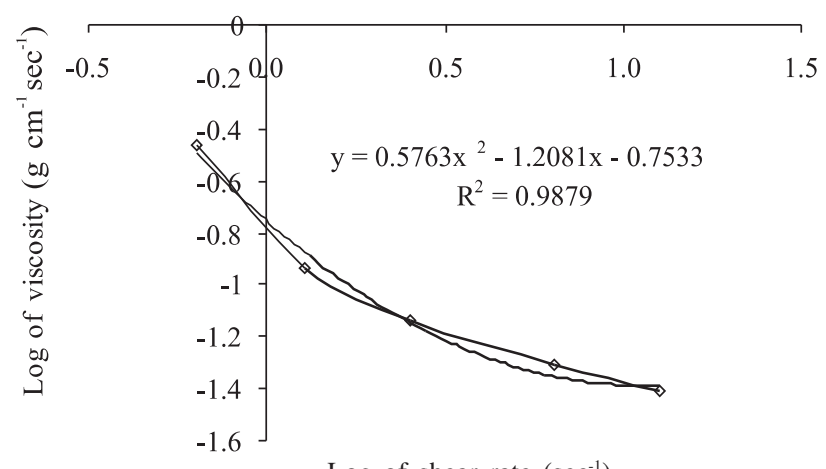

Log of shear rate $\left(\mathrm{sec}^{-1}\right)$

Fig 7 Plot of logarithmic of viscosity and logarithmic of shear rate of a liquid culture of B. pumilus RXAIII-5.

1949) as described above (Fig 5). Calculated results are shown in Table 2.

Rheology of the Cultivation Liquid. The data obtained shows that the viscosity of the medium decreases over the course for culturing the bacterium (Fig 6). This would influence the flow performance of the medium in a bioreactor. Flow pattern changes of the liquid would alter mass and heat transfer and can cause inappropriate oxygen distribution in the bioreactor medium.

Fig 6 b shows that the liquid culture be haves as a nonNewtonian fluid, its viscosity changes with the change of shear rate. As the liquid is non-Newtonian, then it is necessary to give special attention to the consistency index (k) and the index (n) of liquid behavior to determine the properties of the liquid culture. These linear regression relationship between the log of sheared rate and the log of viscosity show a slope of $\mathrm{n}-1$, with an intercept of antilog $\mathrm{k}$ (Fig 7).

\section{DISCUSSION}

In addition to growth medium, bacterial cultivation required particular environmental conditions for supporting their good growth. The environmental factors include 
physical factors such as temperature and agitation, as well as chemical environment which can influence the physical properties of cells. Cell membranes are greatly affected by temperature, while their permeability depends on the content and type of lipid in the membrane. A temperature increase of $5-10{ }^{\circ} \mathrm{C}$ over the optimum temperature may cause lysis and kill the cells of microorganisms.

The total content of soluble protein begins to increase at the start of the exponential growth phase. High total enzymes (xylanase activity) were also produced during this phase. This phenomenon shows that xylanase is actually a primary metabolic product that is associated with cell growth. The enzyme is used for cell growth as well as for hydrolyzing xylanase as its substrate.

The results also indicate that even tif the growth conditions of a bacterial isolate is made basic (high $\mathrm{pH}$ ) from the start, the experimental results indicate that it does not automatically require a high $\mathrm{pH}$ for optimum growth. Bacillus pumilus RXAIII-5 still survivies at $\mathrm{pH} 9.9$ while the optimum growth is at neutral $\mathrm{pH}(\mathrm{pH} 7)$. A similar phenomenon was reported by Yang et al. (1995). In his experiments with Bacillus sp., which were able to survive at $\mathrm{pH} 11.5$, resulted in xylanase activity of $49 \mathrm{U}^{-\mathrm{ml}^{-1}}$ with an optimum of $\mathrm{pH} 7$. This result agrees with funding of Rawashdeh et al. (2005) who reported a xylanase from Streptomyces sp (strain lb 24D) with a $\mathrm{pH}$ optimum of $\mathrm{pH}$ 6-7.

To scale-up xylanase production it is necessary to conduct a study on the mathematical model for cultivation kinetics. This model was obtained by entering data of the kinetics parameters into the Monod equation (Monod 1949), and then excecuting it to give a validation. Four parameters i.e. specific-growth, biomass production, substrate consumption, and enzyme production (xylanase activity) rates were studied in the cultivation kinetics. The resulting data are useful for determinating the optimum conditions, i.e. the strategy for obtaining optimum substrate additions and studying mathematical models for the fermentation industry.

The specific growth rate (ì) was not constant asit depends on the physical and chemical environment. The specific growth rate is a slope obtained from a linear relationship between time of cultivation and natural logarithm (ln) of dried cell weight of a bacterial culture. In this experiment 6 treatments resulted in specific growth rates (i) of $0.067-$ 0.082 an hour (Table 2). The highest specific growth rate was obtained at $150 \mathrm{rpm}$ and $0.5 \mathrm{vvm}$ for agitation and aeration rates, respectively, and the minimum specific growth rate was obtained at $100 \mathrm{rpm}$ and $0.5 \mathrm{vvm}$ for the agitation and aeration rates. Lower aeration reduced the specific growth rate. At an aeration rate of 0.5 and $1.0 \mathrm{vvm}$, with agitation rate of $100 \mathrm{rpm}$, the specific growth rates were 0.067 and 0.072 an hour, respectively.

Microorganism growth and xylanase activity is closely related to substrate consumption. This phenomenon was shown by the equilibrium of substrate consumption, microorganism growth rate and xylanase activity (enzyme production). The efficiency of each of the three parameters was shown as the yield i.e. Yp/x defined as the efficiency of substrate consumption for the enzyme production, $\mathrm{Yx} / \mathrm{s}$ as the efficiency of substrate consumption for the cell biomass production, and $\mathrm{Yp} / \mathrm{x}$ as the efficiency of the enzyme production by cell biomass. The value of the three parameters was calculated by the Monod equation (Monod 1949), and the result are presented in Fig 5.

The highest efficiency for substrate consumption for cell biomass production ( $\mathrm{Yx} / \mathrm{s}$ ) was $1.18 \mathrm{~g} \mathrm{~g}^{-1}$ at an agitation rate of $200 \mathrm{rpm}$ and an aeration rate of $1.0 \mathrm{vvm}$ (Table 2). The increase in the efficiency of the substrate consumption ( $\mathrm{Yx} / \mathrm{s})$ and also will be increases the efficiency of enzyme production by cell biomass (Yp/x). The enzyme production was greatly affected by cell biomass production.

Biomass production was directly related to substrate consumption. In these experiments, the highest biomass was achieved at levels of aeration with agitation rates of $1.0 \mathrm{vvm}$ and $200 \mathrm{rpm}$, respectively. This indicates that increasing the aeration and agitation rates will increase the availability and facilitate the distribution of oxygen supply in the bioreactor. The lag phase could be shortened with a faster rate of aeration.

The oxygen consumption by microorganisms was related to the aeration and agitation of the cultivation process. Low levels of oxygen supply would reduce enzyme, antibiotic, and organic acid production by the microorganism. Based on the data on the cultivation kinetics of B. pumilus RXAIII5 in liquid culture, an optimum condition was selected to obtain the highest efficiency of xylanase activity using biomass as a parameter. An optimum condition was obtained at the aeration and agitation rates of $1.0 \mathrm{vvm}$ and $200 \mathrm{rpm}$, respectively with a recorded $\mathrm{Yx} / \mathrm{s} 1.18 \mathrm{~g} \mathrm{~g}^{-1}$ substrate, $\mathrm{Yp} / \mathrm{s}$ $50.74 \mathrm{U} \mathrm{g}^{-1}$ and $\mathrm{Yp} / \mathrm{x} 43.91 \mathrm{U} \mathrm{g}^{-1}$ biomass.

Our study on the flow behavioural and properties of liquid culture medium (rheology) are very useful for bioreactor design. The properties of the fluid flow of a liquid culture medium affected the homogeneity of the liquid culture components. Fluid viscosity and flow properties affected significantly the transfer of components entering and leaving the cell.

Fermentation broth was found to behave as shear thickening fluid $(n=0.3212)$, and consistent index $(k=0.179 \mathrm{~g}$ $\mathrm{cm}^{-1}$ second $\left.{ }^{-1}\right)$. Liquid culture is a non-Newtonian and mathematical calculation giving $\mathrm{n}=0.32$ and $\mathrm{k}=0.18 \mathrm{~g} \mathrm{~cm}^{-1}$. second $^{-1}$. This means that the $\mathrm{k}>0$ and $0<\mathrm{n}<1$ which indicates the liquid has pseudoplastic properties. This result differ from funding of Mora-Alvarez (1999) who reported the rheological characterization of fermentation broth from xylanase production by Trichoderma longibrachiatum broths with $\mathrm{n}$ ranged from 1.14 to 2.15 .

This experiment also means that the viscosity decrease is due to an increase in the shear rate. Increasing the speed of shaking would reduce the liquid viscosity. Thus, the flow of liquid around the impeller is much more rapid than that at the surface as well as around the wall of the bioreactor. Therefore, the rheology of the liquid medium influences the energy required for the operation of a bioreactor.

To agitate a non-Newtonian liquid requires higher energy as compared with that of a Newtonian liquid. The calculated Rheynold number (NRe) of the liquid was $6.9 \times 10^{3}$ i.e. larger than $10^{3}$. The value of $\mathrm{NRe}$ indicates that the liquid has 
turbulent properties (Doran 1995). The power value (Np) was determined by fitting the $\mathrm{NRe}$ value on the curve of power function versus NRe. For a six-blade-turbine impeller the $\mathrm{Np}$ value obtained was 5.0. The energy requirement to run the impeller with $0.228 \mathrm{HP}$ (horse power) for aerating the system per unit volume was $0.2665 \mathrm{HP} \mathrm{m}^{-3}$. The value is then incorporated into the calculation for scaling up the bioreactor. Due to the complexity of the properties of the liquid medium, the bioreactor design for bacterial culture is very critical. Ones the course of the reaction, the rheology of the liquid medium changed from pseudoplastic to Newtonian due to the decomposition of xylan (polymer) to xylose (monomer).

\section{REFERENCES}

Ball AS, McCarthy AJ. 1989. Production and properties of xylanases from actinomycetes. J Appl Bacteriol 66:439-444.

Beg QK, Kapoor M, Mahajan L, Hoondal GS. 2001. Microbial xylanases and their industrial applications; a review. J Appl Micribiol Biotechnol 56:326-338.

Belfaquih N, Jaspers C, Kurzatkowski W, Penninckx MJ. 2002. Properties of Streptomyces sp. Endoxylanases in relation to their applicability in kraft pulp bleaching. World J Microbiol Biotechnol 18:699-705.

Bradford MM. 1976. A rapid and sensitive methods for quantitative proteins utilizing the principles of protein dye binding. Anal Biochem 72:248-354.

Doran PM. 1995. Bioproses Engineering Principles. Academic Pr Limited. London. p 51-103.

Gilbert HJ, Hazlewood GP. 1993. Bacterial cellulase and xylanases. J Gen Mikrobiol 139:187-194.

Hrmova M, Biely P, Vrsanska M, Petrakova E. 1984. Induction of cellulose and xylanase-degrading enzyme complex in the yeast of Trichosporon cutaneum. J Arch Microbiol 138:371-376,

Kheng PP, Omar IC. 2005. Xylanase production by alocal isolate, Aspergillus niger USM AI 1 via solid state fermentation using palm kernel cake (PKC) as substrate. Songklanakarin. J Sci Technol 27:325-336.
Kubata KB, Horitsu HK, Kawai, Takamizawa K, Suzuki T. 1992. Xylanase I of Aeromonas caviae ME-1 Isolated from the intentine of a herbivorous insect (Samia cyrithia pryeri). J Bioschi Biotech Biochem 56:1463-1464.

Liu W, Lu Y, Ma G. 1999. Induction and glucose repression of endo$\beta$-xylanase in the yeast Trichosporon cutaneum SL409. Process Biochem 34:67-72.

Monod J. 1949. The Growth of bacterial cultures. Ann Rev Microbiol $3: 371-374$.

Rawashdeh R, Saadoun I, Mahasneh A. 2005. Effect of cultural condition on xylanase production by Streptomyces sp. (strain $\mathrm{lb}$ 24D) and its potential to utilize tomato pomace. African $J$ Biotechnol 4:251-255.

Richana N, Lestina P, Irawadi TT. 2004. Karakterisasi lignoselulosa: xilan dari limbah tanaman pangan dan pemanfaatannya untuk pertumbuhan bakteri RXA III-5 penghasil xilanase. J Penelitian Pertanian 23:171-176.

Ruiz-Arribas A, Fernandez-Abalos JM, Sanches P, Gardu AL, Santamaria RI. 1995. Over production, purification and biochemical characterization of xylanase I (xys 1) from Streptomyces halstedii. JM8. Appl Environ Microbiol 61:24142419.

Saha BC. 2002. Production, purification, and properties of xylanase from a newly isolated Fusarium proliferatum. Process Biochem 37:1279-1284.

Saurabh G, Kuhad RC, Bharat B, Hoondal GS. 2001. Improved xylanase production from a haloalkalophilic Staphylococcus sp. SG-13 using inexpensive agricultural residues. World J Microbiol Biotechnol 17:5-8.

Sunna A, Antranikian G. 1997. Xylanolytic enzyme from fungi and bacteria. Crit Rev Biotechnol 17:39-67.

Tonukari NJ, Scott-Craig JS, Walt JD. 2002. Influence of carbon source on the epression of Cochliobulus carbonum xylandegrading enzyme genes. African J Biotechnol 1:64-66.

Viikari L, Kantelinen A, Sundqvist J, Linko M. 2001. Xylanases, in bleaching: from an idea to the industry. FEMS Microbiol Rev 13:335-350.

Winterhalter C, Liebl W. 1995. Two extremly thermostable xylanase of the hyperthemophilic bacterium Thermotoga maritima MSBB. App Environ Microbiol 61:1810-1815.

Yang VW, Zhuang Z, Elegir G, Jeffries TW. 1995. Alkaline-active xylanase produced by an alkaliphilic Bacillus sp. (VI-4) isolated from kraft pulp. J Ind Microbiol 15:434-441. 